\title{
Зообентос водоемов в зоне влияния Оленегорского горно-обогатительного комбината (АО «Олкон»)
}

Валькова C.A.

Институт проблем промышленной экологии Севера КНЦ РАH, Anamumbl,Valkova@inep.ksc.ru

\begin{abstract}
Аннотация. Исследованы состав и структура зообентоса ряда водоемов, расположенных в зоне влияния горнодобывающего предприятия Оленегорский ГОК (АО «Олкон»). Основу численности и биомассы зообентоса всех водоемов формируют двустворчатые моллюски подсем. Euglesinae и крупные формы личинок хирономид подсемейств Chironomini и Tanypodinae, что свидетельствует о развитии процессов эвтрофикации вод. Количественные показатели зообентоса зависели от степени загрязнения донных отложений. По уровню биомассы бентофауны исследованные водоемы относятся к мезотрофному или эвтрофному типу.
\end{abstract}

Ключевые слова: зообентос, озера, загрязнение, горнодобывающее предприятие.

\section{Zoobenthos of lakes in the influence zone of the Olenegorsk mining plant (JSC «Olkon»)}

\author{
Valkova S.A. \\ Institute of the Industrial Ecology Problems of the North KSC RAS, Apatity, Valkova@inep.ksc.ru
}

\begin{abstract}
The taxonomic composition and structure of zoobenthos of lakes located in the influence zone of the Olenegorsky mining enterprise (JSC «Olkon») were investigated. The biomass of zoobenthos of all water bodies is mosty represented by mollusks (subfamily. Euglesinae) and large forms of the chironomid larvae of the Chironomini and Tanypodinae subfamilies, which indicates eutrophication processes in waters. Quantitative indicators of zoobenthos depended on the degree of contamination of sediments. The studied lakes refer to the mesotrophic or eutrophic type by the amount of zoobenthos biomass.
\end{abstract}

Key words: zoobenthos, lakes, pollution, mining plant.

Акционерное общество «Оленегорский горно-обогатительный комбинат» (АО «ОЛКОН») одно из крупнейших горнодобывающих предприятий Мурманской области. Комбинат осуществляет добычу и переработку железосодержащих руд. Восточный участок Южно-Кахозерского месторождения железистых кварцитов расположен в центральной части Кольского полуострова в 4 км к западу от ст. Оленегорск Октябрьской железной дороги, в пределах муниципального образования г. Оленегорск.

В 2010 г. ИППЭС КНЦ РАН проведены гидрохимические и гидробиологические исследования ряда водных объектов, расположенных в районе влияния Восточного участка Южно-Кахозерского месторождения с целью оценки их современного экологического состояния. Изучение зообентоса проводилось на озерах: Большая Имандра (губа Куреньга), Старое, Круглое, Пермусозеро, Кахозеро и Колозеро.

Озеро Пермусозеро расположено в 1.5 км на восток от г. Оленегорск, относится к водосбору оз. Бол. Имандра. Это среднее (площадь озера $24.2 \mathrm{~km}^{2}$ ) озеро ледникового происхождения с изрезанными берегами. Территория водосборной площади относится к лесотундровой зоне. Берега озера невысокие, каменистые, местами встречаются заболоченные участки, в прибрежной зоне распространены валунные отложения. Водоем загрязняется сточными водами Оленегорского механического завода и предприятиями Минобороны РФ, на восточном берегу расположен военный городок «Высокий».

Озеро Верхнее Старое расположено в 9 км на юг от г. Оленегорск, относится к водосбору ручья Хариусный. Это малое (площадь озера 2.4 км²) озеро ледникового происхождения. Восточный берег озера высокий, каменистый, на западном берегу местами встречаются заболоченные участки. По берегам распространен кустарник, березовые и сосновые леса. На западном берегу расположены отвалы Оленегорского горно-обогатительного комбината АО «Олкон». 
Озеро Круглое расположено в 3.5 км на юг от г. Оленегорск, относится к водосбору реки Куреньга. Это малое (1.36 км²) озеро ледникового происхождения. Берега озера невысокие, заболоченные. По берегам распространен кустарник, березовые и сосновые леса. На южном берегу расположен дачный поселок.

Озеро Кахозеро расположено в 3 км на северо-запад от г. Оленегорск, относится к водосбо-

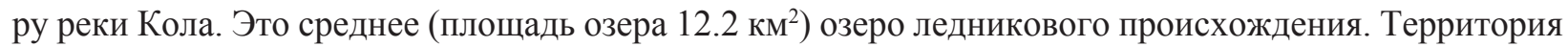
водосборной площади по типу ландшафтов относится к лесотундровой зоне. Берега озера невысокие, каменистые, местами встречаются заболоченные участки. По берегам распространен кустарник, березовые, сосновые и еловые леса. В прибрежной зоне озера распространены валунные отложения. На восточном берегу водоема расположены отвалы Оленегорского горно-обогатительного комбината АО «Олкон».

Озеро Колозеро расположено в 5 км на север от г. Оленегорска, относится к водосбору реки Кола. Это среднее (площадь озера 66.28 км²), состоящее из двух плесов озеро ледникового происхождения. Озеро вытянуто в меридиональном направлении и лежит в глубокой депрессии, пересекающей Кольский полуостров от Кольского до Кандалакшского залива. Максимальная глубина озеpa 29 м. Основным источником загрязнения озера являются хозяйственно-бытовые сточные воды г. Оленегорска, сбрасываемые в южной части водоема.

Плес Большая Имандра, губа Куреньга. Плес Большая Имандра является самой глубоководной частью озера Имандра (максимальная глубина 67 м, средняя - 14.7 м). Западное побережье плеса сильно изрезанно, изобилует большим количеством губ, из которых Куреньга (Куренглухт) является наиболее крупной.

Отбор проб зообентоса из глубоководных участков водоемов осуществлялся дночерпателем Экмана-Берджа с площадью захвата грунта $1 / 40$ м² в 3-х кратной повторности. Анализ бентосных проб проводили с использованием рекомендованных стандартных методик (Руководство..., 1992). Определение беспозвоночных проводилось по трем определителям (Определитель..., 1975, 1999, 2016). Биомасса бентосных беспозвоночных рассчитывалась по сырому весу. Для фиксирования проб использовали 4 \%-й формалин или 70-80 \%-й спирт. Трофический статус водоемов по уровню развития зообентоса оценивали по шкале С.П. Китаева (2007).

Гидрохимическая характеристика исследованных водоемов. Все поверхностные воды по кислотности «нормальные» с определенной долей условности (ГОСТ 17.1.2.04-77). Большинство поверхностных вод «пресные ксеногалобные», за исключением оз. Верх. Старое, воды которого характеризуются как «пресные среднеминерализованные». По классу и группе озера Кахозеро и Колозеро «гидрокарбонатные кальциевые», озера Пермусозеро и Круглое губа Куреньга (плес Бол. Имандра) - «гидрокарбонатные натриевые». Воды озера Верх. Старое относятся к «сульфатным кальциевым», а губы Куреньга (плес Бол. Имандра) - к «сульфатным натриевым» (Даувальтер, 2019). Во всех исследованных водоемах наблюдается превышение нормативов для железа, вероятно, основной причиной является значительный вклад «болотных» вод в формирование состава поверхностных вод, а также высокие концентрации соединений азотной группы, связанное поступлением фильтрационных вод из отстойника и отвалов АО «Олкон», на котором для проведения буровзрывных работ используют взрывчатые вещества, содержащие азотные соединения (Даувальтер, 2019) (табл. 1).

В поверхностных слоях донных отложений исследуемых водоемов отмечается довольно значительное увеличение концентраций $\mathrm{Cu}, \mathrm{Ni}, \mathrm{Co}, \mathrm{Zn}$, также отмечено значительное превышение фоновых концентраций халькофильных элементов: $\mathrm{Cd}, \mathrm{Pb}$, As, Hg. Поэтому эти чрезвычайно токсичные в повышенных концентрациях элементы можно отметить в качестве основных загрязняющих элементов, наряду с $\mathrm{Ni}$ и $\mathrm{Cu}$.

Наибольшее значение степени загрязнения $\left(\mathrm{C}_{\mathrm{d}}\right)$, рассчитанной как сумма коэффициентов загрязнения восьми ТМ и металлоида $(\mathrm{Cu}, \mathrm{Ni}, \mathrm{Co}, \mathrm{Zn}, \mathrm{Cd}, \mathrm{Pb}, \mathrm{Hg}$ и $\mathrm{As})$, отмечено в оз. Старое $\left(\mathrm{C}_{\mathrm{d}}=106.1\right)$, назападном берегу которого расположены отвалы Оленегорского горно-обогатительного комбината АО «Олкон», стоки с которых, возможно, вносят значительный вклад в загрязнение озера. 
На втором месте по степени загрязнения стоит губа Куреньга плеса Большая Имандра $\left(\mathrm{C}_{\mathrm{d}}=61.6\right)$, долгое время загрязняемая стоками и выбросами комбината «Североникель», а также АО «Олкон». Пермусозеро, являющееся источником питьевого водоснабжения г. Оленегорска и АО «Олкон», также интенсивно загрязняется, о чем свидетельствуют высокие значения степени загрязнения $\left(\mathrm{C}_{\mathrm{d}}=47.3\right)$. Остальные исследованные озера также характеризовались высокими значениями степени загрязнения (согласно классификации (Håkanson, 1980) $\mathrm{C}_{\mathrm{d}}>32$ ): озеро Кахозеро - 42.4, озеро Колозеро - 38.0. Оз. Круглое отличалось наименьшими значениями степени загрязнения $\mathrm{C}_{\mathrm{d}}-27.3$ (Даувальтер, 2018).

Таблица 1. Результаты комплексных аналитических исследований поверхностных вод в зоне влияния Оленегорского горно-обогатительного комбината (придонные слои).

Table 1. Results of complex analyses of surface waters in the influence zone of the Olenegorsk mining and processing plant (bottom layers).

\begin{tabular}{|c|c|c|c|c|c|c|c|c|c|c|c|}
\hline Объект & 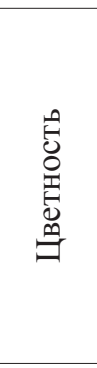 & 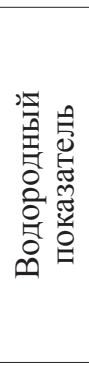 & 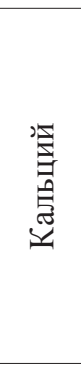 & $\begin{array}{l}\text { 瓷 } \\
\text { 恶 }\end{array}$ & 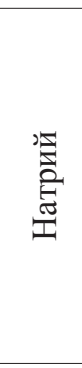 & 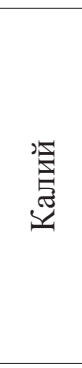 & 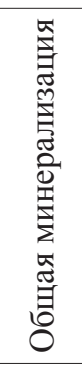 & 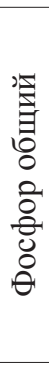 & 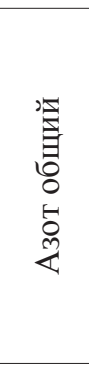 & 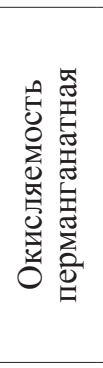 & 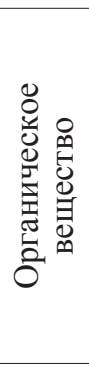 \\
\hline Условные обозначения & - & $\mathrm{pH}$ & $\mathrm{Ca}^{2+}$ & $\mathrm{Mg}^{2+}$ & $\mathrm{Na}^{+}$ & $\mathrm{K}^{+}$ & $\sum \mathrm{M}$ & $\mathrm{P}$ & $\mathrm{N}$ & - & TOC \\
\hline Размерность & Град. & - & & & $\mathrm{M \Gamma} / \pi$ & & & \multicolumn{2}{|c|}{ мкг/л } & \multicolumn{2}{|c|}{$\mathrm{MгO} / л$} \\
\hline оз. Круглое & 26 & 7.19 & 3.05 & 1.32 & 3.67 & 0.96 & 31.4 & 12 & 248 & 6.58 & 6.6 \\
\hline губа Куреньга & 9 & 7.35 & 3.60 & 1.20 & 11.3 & 2.12 & 59.0 & 14 & 233 & 3.12 & 3.9 \\
\hline оз. Старое & 13 & 7.56 & 17.5 & 4.84 & 5.13 & 2.20 & 97.4 & 5 & 4440 & 4.00 & 4.6 \\
\hline оз. Кахозеро & 20 & 7.34 & 7.18 & 2.20 & 2.65 & 1.18 & 46.8 & 7 & 1034 & 6.01 & 6.1 \\
\hline оз. Пермусозеро & 27 & 7.23 & 2.41 & 1.08 & 3.15 & 0.74 & 26.1 & 13 & 301 & 6.51 & 6.5 \\
\hline оз. Колозеро & 11 & 7.47 & 8.72 & 2.40 & 3.40 & 2.71 & 62.4 & 12 & 305 & 3.51 & 4.2 \\
\hline
\end{tabular}

В составе зообентоса глубоководных участков исследованных водоемов отмечены двустворчатые моллюски семейства Sphaeriidae (Spheriinae, Euglesinae, Pisidiinae), хирономиды рода Chironomus, Monodiamesa bathyphila Kieffer, 1918 и Procladius (Holotanypus) choreus Meigen, 1804. Олигохеты были представлены обычными для водоемов региона сем. Naididae и Tubificidae (табл. 2).

Таблица 2. Таксономический состав и количественные показатели зообентоса.

Table 2. The taxonomic composition and quantitative indicators of zoobenthos.

\begin{tabular}{|c|c|c|c|c|c|c|}
\hline Группа & Круглое & Колозеро & Пермусозеро & Старое & Кахозеро & $\begin{array}{c}\text { губа } \\
\text { Куреньга }\end{array}$ \\
\hline Oligochaeta & - & + & - & + & - & + \\
\hline Euglesinae & + & + & + & + & + & + \\
\hline Chironominae & + & + & + & + & - & + \\
\hline Tanypodinae & - & + & + & - & - & + \\
\hline $\mathrm{N}$, экз./ $\mathrm{M}^{2}$ & 1350 & 986 & 590 & 104 & \multirow{3}{*}{ не опр. } & 280 \\
\hline $\mathrm{B}, \Gamma / \mathrm{M}^{2}$ & 23 & 8 & 2.8 & 0.5 & & 1.2 \\
\hline Трофический статус & эвтроф. & мезотр. & мезотр. & олиготр. & & олиготр. \\
\hline
\end{tabular}




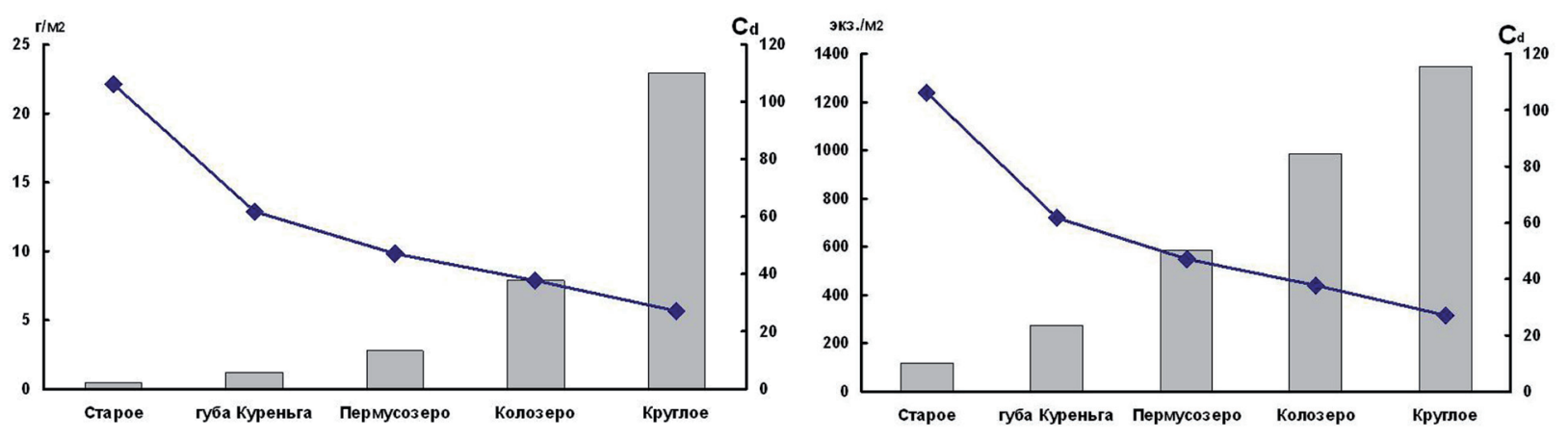

Рис. 1. Зависимость численности и биомассы глубоководного зообентоса (гистограмма) от значений коэффициента степени загрязнения $\left(\mathrm{C}_{\mathrm{d}}\right)$ донных отложений (сплошная линия) исследованных водоемов.

Fig. 1. Relation between the abundance and biomass of zoobenthos (block) and values of the pollution coefficient $\left(\mathrm{C}_{\mathrm{d}}\right)$ of sediments (solid line) of the studied lakes.

Количественные показатели зообентоса были невысоки и в целом соответствовали значениям, характерным для водоемов региона (Яковлев, 2005). Уровень общей численности и биомассы донной фауны зависел от степени загрязнения $\left(\mathrm{C}_{\mathrm{d}}\right)$ донных отложений (рис. 1$)$. Наиболее низкие значения численности и биомассы летнего зообентоса были отмечены для озера Старое, которое загрязняется стоками с отвалов Оленегорского горно-обогатительного комбината. Максимальные показатели обилия бентофауны отмечены для озера Круглое, которое среди исследованных водоемов можно рассматривать как наименее антропогенно-трансформированное (рис. 1). Исключение составляло озеро Кахозеро, донные отложения которого представляли собой ил-сапропель. В составе бентосных сообществ этого водоема были отмечены только единичные экземпляры двустворчатых моллюсков Euglesa sp.

Количественно в составе зообентоса всех исследованных водоемов доминировали двустворчатые моллюски и крупные формы личинок хирономид подсемейств Chironomini и Tanypodinae. Суммарная доля их численности и биомассы варьировала от 80 \% до 100 \% от общего количества беспозвоночных. Такая структура является характерной чертой организации зообентосных сообществ глубоких частей эвтрофных водоемов, где формируются относительно однородные «техногенные» пелофильные биоценозы (Яковлев, 2005).

Таким образом, все исследованные водоемы характеризуются обедненным качественным составом бентосных сообществ. В составе макрозообентоса доминируют хирономиды рода Chironomus и двустворчатые моллюски подсемейства Euglesinae - эвритопные, обладающие широкой экологической пластичностью группы беспозвоночных. Количественные показатели зообентоса проявляют определенную специфику в зависимости от степени загрязнения донных отложений водоема. По уровню развития зообентоса исследованные водоемы относятся к мезотрофному или эвтрофному типу, тогда как для большинства фоновых водоемов региона характерен олиготрофный трофический статус.

Статья подготовлена в рамках выполнения госзадания ИППЭС КНЦ РАН, тема «Закономерности функционирования арктических пресноводных экосистем в условиях изменения глобального климата и усиления антропогенного воздействия», № гос. рег.: 0226-2019-0045.

\section{Литература}

1. Даувальтер В.А. Загрязнение донных отложений озер Оленегорского района Мурманской области тяжелыми металлами // Труды Ферсмановской научной сессии ГИ КНЦ РАН. 2018. №15. С. 437-440.

2. Даувальтер В.А. Гидрохимия озер в зоне влияния стоков производства железорудного сырья // Вестник МГТУ. 2019. № 1 (в печати).

3. Китаев С.П. Основы лимнологии для гидробиологов и ихтиологов. Петрозаводск: Карельский НЦ РАН, 2007. $395 \mathrm{c}$. 
4. Определитель зоопланктона и зообентоса пресных вод Европейской России. Т. 2. Зообентос. М.; СПб.: КМК. 2016. 457 c.

5. Определитель пресноводных беспозвоночных Европейской части СССР (планктон и бентос) / Под ред Л.А. Кутиковой, В.Я. Старобогатова. Гидрометеоиздат. 1977. 510 с.

6. Определитель пресноводных беспозвоночных России и сопредельных территорий. Т. 4. Высшие насекомые. Двукрылые / Под общ. ред. С.Я. Цалолихина. СПБ.: Наука. 1999. 1000 с.

7. Руководство по методам гидробиологического анализа поверхностных вод и донных отложений / отв. ред. В.А. Абакумов и др. СПБ.: Гидрометеоиздат. 1992. 318 с.

8. Яковлев В.А. Пресноводный зообентос северной Фенноскандии (разнообразие, структура и антропогенная динамика). Апатиты: Изд-во КНЦ РАН. 2005. Ч. 2. 145 с.

9. Håkanson L. An ecological risk index for aquatic pollution control - a sedimentological approach // Water Res. 1980. V. 14. P. 975-1001. 